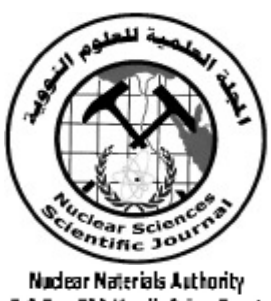

ISSN 2314-5609

Nuclear Sciences Scientific Journal

6, 137- 152

2017

http://www.ssnma.com

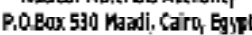

\title{
GEOLOGY AND RADIOACTIVITY OF MUSCOVITE LEUCOGRANITES AT NORTH WADI ABU RUSHEID AREA, SOUTH EASTERN DESERT, EGYPT
}

\author{
MOHAMED A. RASHED \\ Nuclear Materials Authority, P. O. Box 530 El Maadi, Cairo, Egypt.
}

\begin{abstract}
The study area is located at north Wadi Abu Rusheid and is composed of ophiolitic mélange (the oldest), cataclastic rocks, biotite granites and muscovite leucogranites (the youngest). The muscovite leucogranites are found as dyke like body intruded between ophiolitic mélange and cataclastic rocks. Petrographically, the muscovite leucogranites are composed mainly of quartz, plagioclase of albitic composition, potash feldspare and muscovite. Zircon, thorite, uranophane and opaques as accessories.

Geochemically, the muscovite leucogranites are peraluminous in nature, crystallized from relatively sodic rich magma and related to calc-alkaline series. The muscovite leucogranites are belong to A-type, emplaced during within plate tectonic setting and intruded in a continental crust with thickness $<20 \mathrm{~km}$.

The muscovite leucogranites have high contents of $\mathrm{Zr}, \mathrm{Y}, \mathrm{Pb}$ and $\mathrm{Nb}$ and moderate contents of $\mathrm{Zn}$, $\mathrm{Ba}, \mathrm{Cu}, \mathrm{Sr}$ and $\mathrm{Rb}$. The mineralogical study of the muscovite leucogranites is characterized by presence of radioactive minerals (uranophane and thorite) and zircon. From radioactivity point of view the muscovite leucogranites up to $250 \mathrm{ppm} \mathrm{eU}$ and $1146 \mathrm{ppm}$ eTh and related to magmatic origin. The muscovite leucogranites lose some of their uranium contents which migrated towards the cataclastic rocks along bedding planes and re-deposited on their fracture planes.
\end{abstract}

\section{INTRODUCTION}

Egyptian granitoid rocks classified into the: 1) syn- to late orogenic older granitoid assemblages (880-610 Ma) emplaced during the mature intra-oceanic island-arc stage (Ragab et al., 1989); and 2) post-orogenic to anorogenic younger granitoid assemblages (600$475 \mathrm{Ma})$. The older granitoids are considered to be a product of partial melting of a mantle wedge with little or no crustal contamination (Hussein et al., 1982). The younger granitoids, commonly forming small plutons (1-10 km2), are confined to regional structural weaknesses of northwest-southeast and north-south directed rifting in northernmost Afro-Arabia (Stern, 1985). They are lithophile light ele- ment (LILE) enriched calc-alkaline to mildly alkaline rocks with I-type affinity, but some of them have recently been classified as Atype granitoids (AbdeI-Rahman and Martin, 1990; Hassanen et al., 1995; Hassanen and Harraz, 1996; EI-Sayed, 1998). However, both the I- and A-type Egyptian younger granitoids are epizonal plutons emplaced at shallow crustal levels (AbdeI-Rahman and Martin, 1987; Hassanen, 1997).

Leucogranites are typical products of collisional orogens, which found in orogenic terranes of different age. Characteristics of these collisional leucogranites show that they were derived from predominantly pelitic sources at the veining stages of deformation and meta- 
morphism in upper plates of thickened crusts. Once generated, the leucogranite magmas ascended as dykes and were emplaced within shallower parts of their source sequences. In these orogenic belts, there was a strong connection between deformation, metamorphism and granite generation (Nabelek and Mian, 2004).

In Egypt, peraluminous leucogranites represent phases of late orogenic to an orogenic granite complex. They brought about Mo, Sn, $\mathrm{W}, \mathrm{U}$, and $\mathrm{Nb}-\mathrm{Ta}$ mineralization in the form of stock works or in the quartz veins within the granitic rocks (Hassan et al., 1984, Takla and Nowier et al., 1980). Mahmoud (2009) studied the six exposures of muscovite granites in Wadi El Gemal and their surroundings and found that, the muscovite granites in the study area are strongly peraluminous, crystallized from calc-alkaline magma, I-type granites and within plate environment. Abu El Atta et al. (2013) studied the peraluminous leucogranites at Madinat Nugrus, south Wadi Abu Rusheid area and stated that this granite is monzogranite in composition peraluminous, I-type in characters and originated from highly differentiated magma generated from upper mantle with some contaminations with the crust.

In this paper, the author throw some lights on the geology, mineralogy and geochemistry of uraniferous muscovite leucogranites.

\section{GEOLOGIC SETTING}

The study area is located at north Wadi Abu Rusheid between lat. $24^{\circ} 38^{\prime} 20^{\prime \prime}$ and $24^{\circ}$ $38^{\prime} 40^{\prime \prime} \mathrm{N}$ and long. $34^{\circ} 45^{\prime} 41^{\prime \prime}$ and $34^{\circ} 46^{\prime}$ $00^{\prime \prime}$ E (Fig. 1). Wadi Abu Rusheid area lying about $60 \mathrm{~km}$ southwest Marsa Alam City (Fig. 1) Red Sea region. The basement rocks at this part can be arranged with the oldest as follows:, ophiolitic mélange, cataclastic rocks, biotite granites and muscovite leucogranites. The geology of abu Rusheid area has attracted many workers (e.g. Hassan ,1973; Sabet et al.,1976; El Maghraby 1994; Saleh,1997 and Ibrahim et al.,2004).

\section{Ophiolitic Mélange}

Ophiolitic mélange occurs in the west side of the study area. It composed mainly of mafic-ultrmafic fragments with varying sized masses of serpentinites, metapyroxenites, metagabbros and talc carbonates intermixed in zone of highly pervasively deformed ma-

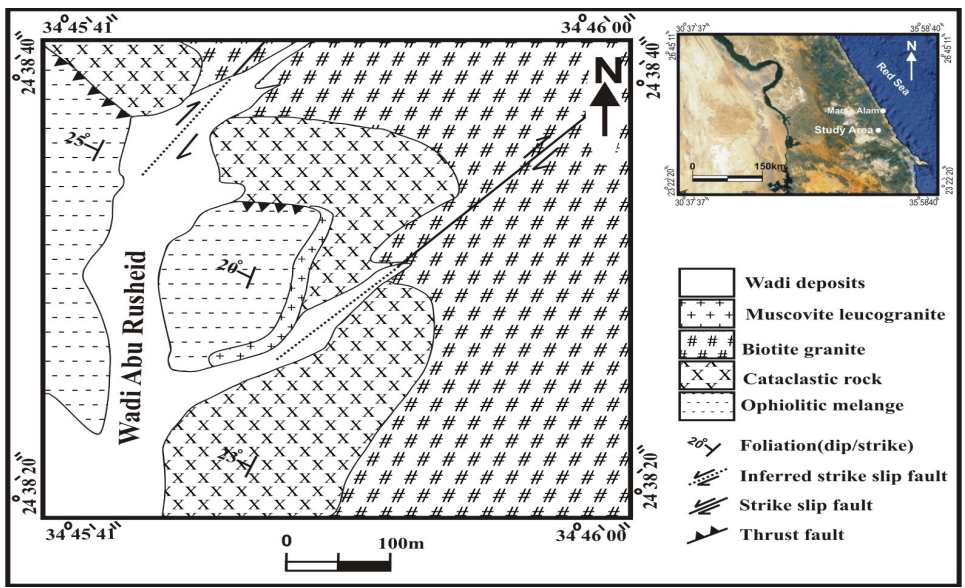

Fig.1: Geologic map of the study area ( Modified after saleh,1997 and Ibrahim et al., 2004) 
trix of metasedimentary origin (Saleh,1997). These rocks are thrusting over cataclastic rocks along NW-SE thrust fault (Fig.1). The mafic-ultramafic fragments occur as subrounded to elongated bodies and characterized by creamy, grey to dark grey in colors (Fig. 2). The matrix of metasediments is fine -grained of greenish grey and whitish grey in color, highly folded and foliated. They are represented by muscovite biotite schist and quartzo-feldspathic biotite schist.

\section{Cataclastic (Mylonite) Rocks}

The cataclastic rocks occur thrusting under the ophiolitic mélange and intruded from east by biotite granites. These rocks are low to medium relief, reddish- to light grey in colors, medium-grained and exhibit gneissosity (Fig. 3) and augen structures. The rocks are

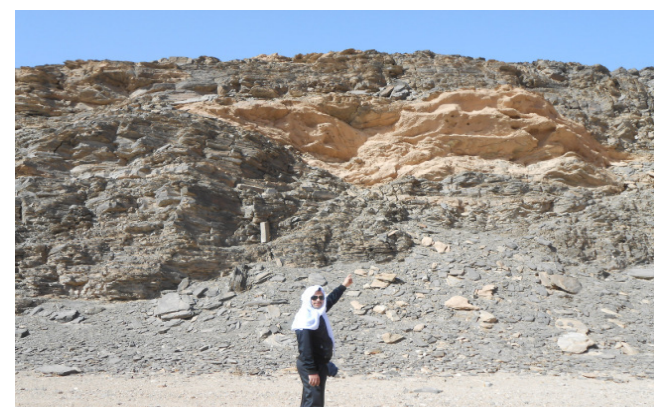

Fig. 2 :Fragment of talc carbonates intermixed in metasedimentary matrix

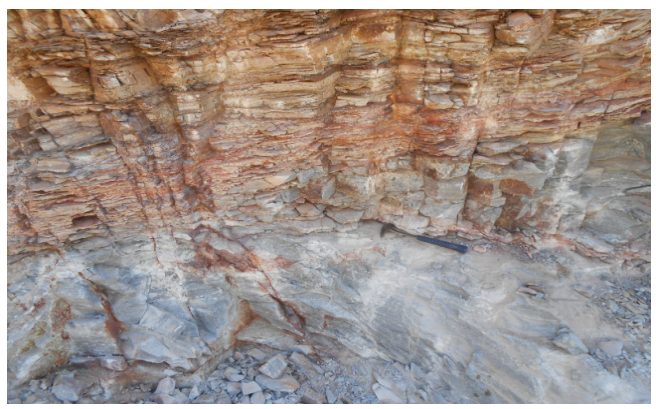

Fig. 3: Highly altered cataclastic rocks highly altered and featured by the frequent presence of pegmatite lenses extending parallel to the foliation planes. The cataclastic rocks affected by many alteration processes as a result of hydrothermal solutions. Due to these alteration processes, the cataclastic rocks show variation of colors from red to yellow colours along faults and joints. The cataclastic rock are mineralized by polymineralization ( $\mathrm{U}, \mathrm{Th}, \mathrm{Pb}, \mathrm{Nb}$,-Ta, and $\mathrm{Zr}$ ) (Ibrahim et al., 2004) and classified into protomylonite, mylonite, ultramylonite and silicified ultramylonite with graditional contacts.

\section{Biotite Granites}

Biotite granites occupy the eastern part of the study area and extend outside the map in the east and north directions. These rocks are intruding through the cataclastic rocks with medium to high relief (Fig. 4), medium to coarse-grained, porphyritic and grey in color.

\section{Muscovite Leucogranites}

The muscovite leucogranites occur close to the thrust fault between the ophiolitic mélange and cataclastic rocks. The muscovite leucogranites are occur as dyke-like body of low topography (Fig. 5) with (2-7 m in width and about $250 \mathrm{~m}$ in length). The muscovite leucogranites are medium-grained, milky white in color, highly sheared, fractured, posses sharp contact and truncate paralling

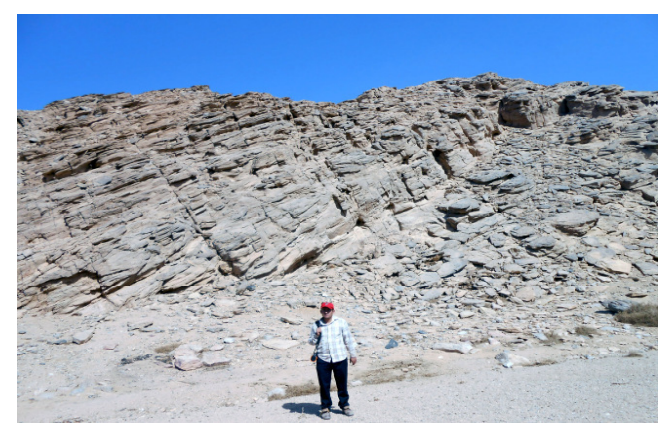

Fig.4: General view of biotite granites 


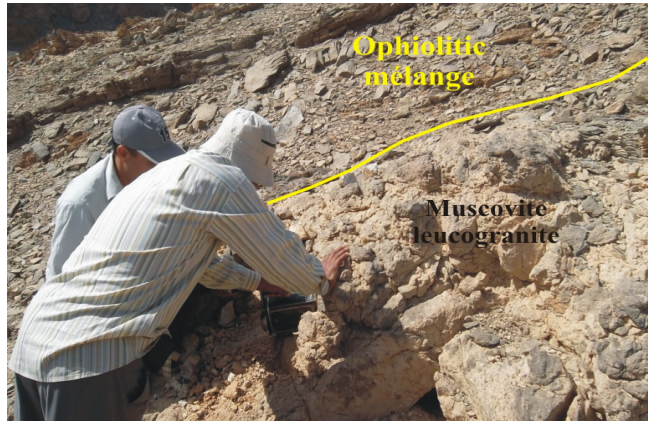

Fig. 5: Photograph showing the low relief and sharp contact of muscovite leucogranites with ophiolitic mélange

the foliation of metasediments with absence of any xenolithes.

The muscovite leucogranites are mainly composed of quartz, plagioclase of albitic composition, potash feldspares and muscovite (Fig.6). Zircon, thorite uranophane and opaques are accessory minerals. Sericite and kaolinite are secondary minerals.

Quartz occurs as subhedral to anhedral crystals of medium-grained as well as fine crystals, occupying the interstices between the other constituents. The crystals exhibiting wavy to undulose extinction with cracking (Fig. 7). Plagioclase occurs as sodic plagioclase (An. ${ }_{4-14}$ ) as subhedral prismatic crystals of medium to fine-grained. The crystals are twinned according to albite and Carlsbad twinning. Albite twinning is more abundant in the muscovite leucogranites than other plagioclase feldspars, and this may be taken as a reflection for low temperature deformation associated with the emplacement of the studied muscovite leucogranites (Shelley, 1993). The crystals of plagioclase are bent, kinked and gliding (Fig. 8). The presence of bent, kinked and gliding of plagioclase lamellae as well as high cracking and strongly undulatory quartz, all these features point to subsolidus deformation (Paterson et al., 1989). Such deformation should be the result of extensive regional thrusting (Greil-

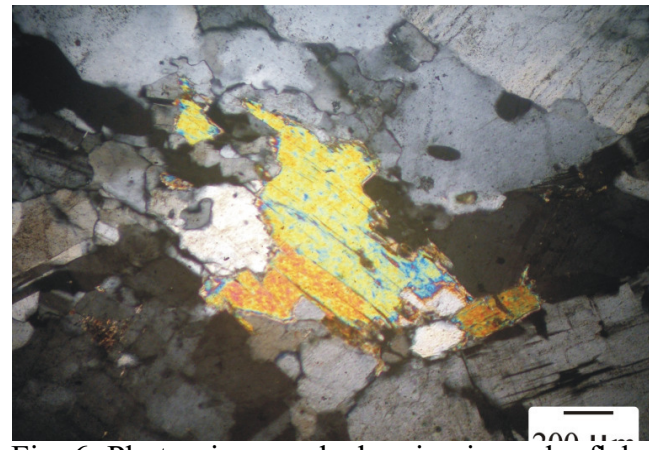

Fig. 6: Photomicrograph showing irregular flaks of muscovite in muscovite leucogranites

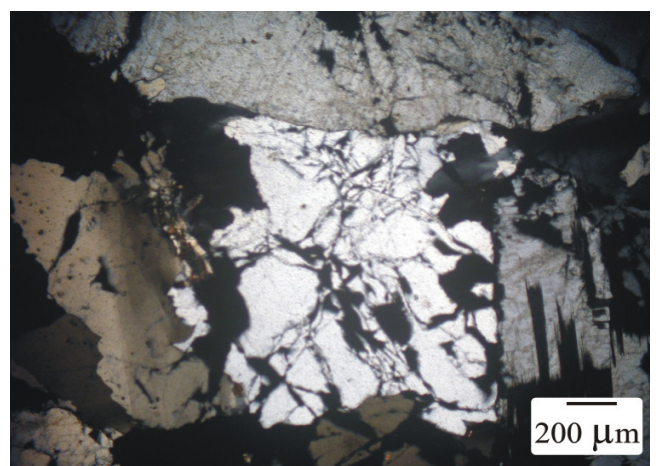

Fig. 7: Photomicrgraph showing high cracking quartz, in muscovite leucogranite

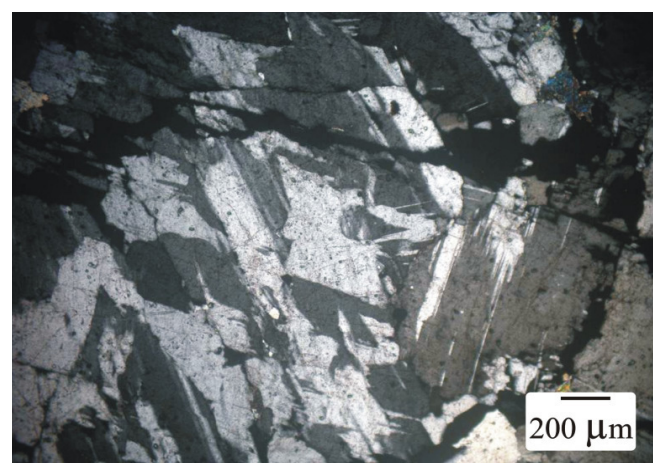

Fig.8: Photomicrograph showing bent and cracked of the plagioclase lamellae in muscovite leucoranites, 
ing et al., 1987), to which the area had been subjected. K-feldspars occur as orthoclase and orthoclase perthite and exhibiting subhedral crystals. K-feldspars contain inclusions of biotite and quartz. The crystals are slightly altered to kaolinite. The presence of two feldspars suggests that the muscovite leucogranites are mostly subsolvus and crystallized under high water pressure (Greenberge, 1981 and Deer et al., 1992). Muscovite occurs as irregular flakes and corroded by other components (Fig.6). Zircon occurs as prismatic crystals associated between the other components of the rock.(Fig. 9). Opaques are rarely contents with skeletal shapes. Thorite occurs as anhedral to subhedral forms filling the interstitial between the crystals of the rock (Fig 10).

\section{GEOCHEMISTRY}

The geochemical study was carried out through the analyses of ten samples from the studied muscovite leucogranites. The major and trace elements were analyzed in Nuclear Materials Authority. The results are listed in Table (1).

\section{Geochemical Features of Muscovite Leucogranites}

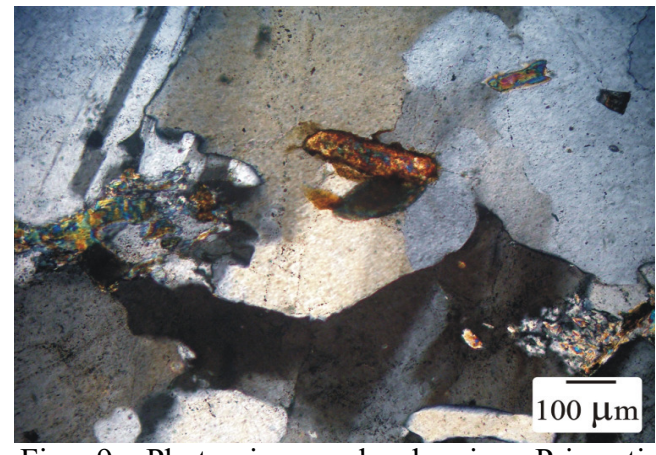

Fig. 9: Photomicrograph showing Prismatic zircon crystals in muscovite leucogranites

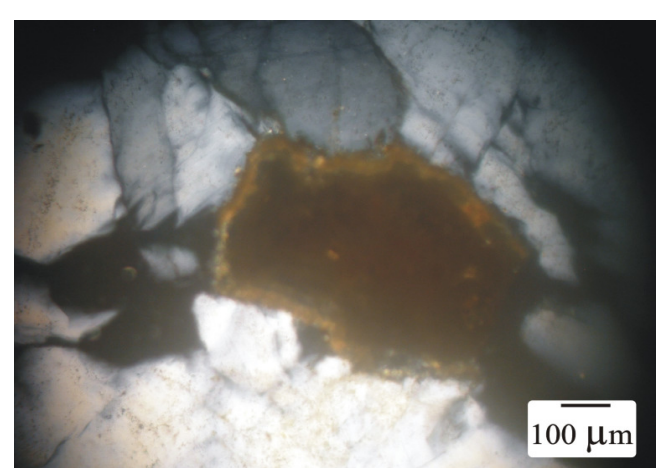

Fig.10: Photomicrograph showing Radioactive mineral (thorite) in muscovite leucogranites

leucogranites are Miaskitic in nature (Goldschmidt, 1954 and Bailey \& Macdonald, 1969) ). The muscovite leucogranites in the study area have a high contents of HFSE such as $\mathrm{Zr}, \mathrm{Y}, \mathrm{Pb}, \mathrm{Ga} \& \mathrm{Nb}$ and moderate contents of $\mathrm{Cu}, \mathrm{Zn}, \mathrm{Ba}, \mathrm{Sr}$ and $\mathrm{Rb}$. According to El Gaby and Habib (1982), Ca/Y ratio decreases continuously and reach its minimum value in the most differentiated granites. The study muscovite leucogranites show low $\mathrm{Ca} / \mathrm{Y}$ ratios (average about $=45$ ).

\section{Geochemical Classifications}

Based on the normative Ab-Or-An ternary diagram was used by Barker (1979) as shown in (Fig. 11). On this diagram, the musof $\mathrm{TiO}_{2}, \mathrm{MgO}, \mathrm{CaO}, \mathrm{FeO}$ and $\mathrm{P}_{2} \mathrm{O}_{5}$. The Agpaitic ratio [molar $\left(\mathrm{Na}_{2} \mathrm{O}+\mathrm{K}_{2}^{2} \mathrm{O}\right) / \mathrm{Al}_{2} \mathrm{O}_{3}$ ] is $<1.0$ (Table 1 ) means that the muscovite 
Table 1: The major oxides in $\mathrm{wt} \%$, trace elements in ppm of muscovite leucogranites, Wadi $\mathrm{Abu}$ Rusheid area.

\begin{tabular}{|c|c|c|c|c|c|c|c|c|c|c|}
\hline Sp.No.. & $\mathbf{1}$ & 2 & 3 & 4 & 5 & 6 & 7 & 8 & 9 & 10 \\
\hline $\mathrm{SiO}_{2}$ & 74.6 & 72.7 & 73.0 & 71.2 & 73.8 & 73.2 & 74.4 & 75.1 & 75.1 & 74.3 \\
\hline $\mathrm{TiO}_{2}$ & 0.1 & 0.05 & o.o1 & 0.03 & 0.15 & o.o1 & 0.27 & o.o1 & 0.01 & o.o1 \\
\hline $\mathbf{A l}_{2} \mathbf{O}_{3}$ & 14.1 & 14.2 & 13.5 & 14.84 & 13.4 & 13.9 & 14.0 & 13.74 & 13.4 & 13.53 \\
\hline FeOt & 0.7 & 1.2 & 1.3 & 1.2 & 1.6 & 1.0 & 1.2 & 0.57 & 0.96 & 0.8 \\
\hline MgO & 0.95 & 0.50 & 0.2 & 1.0 & 0.7 & 0.65 & 0.63 & 0.74 & 0.23 & 0.61 \\
\hline CaO & 1.1 & 1.05 & 0.9 & 1.04 & 1.1 & 1.18 & 1.05 & 1.04 & 0.82 & 1.12 \\
\hline $\mathrm{Na}_{2} \mathrm{O}$ & 4.9 & 4.27 & 4.74 & 4.4 & 4 & 4.6 & 4.5 & 3.7 & 4.4 & 4.10 \\
\hline $\mathbf{K 2 O}$ & 2.3 & 3.17 & 3.26 & 3.26 & 2.8 & 3.26 & 2.72 & 3.19 & 3.69 & 2.69 \\
\hline $\mathbf{P}_{2} \mathbf{O}_{5}$ & 0.62 & 0.65 & 0.98 & 0.76 & 0.71 & 0.98 & 0.36 & 0.38 & 0.56 & 0.69 \\
\hline L.O.I & 0.38 & 0.34 & 0.34 & 0.36 & 0.37 & 0.36 & 0.37 & 0.33 & 0.46 & 0.39 \\
\hline Total & 99.72 & 98.39 & 98.23 & 98.09 & 99.63 & 99.8 & 99.9 & 98.8 & 99.63 & 98.3 \\
\hline ALK & 7.2 & 7.44 & 8 & 7.66 & 6.8 & 7.86 & 7.22 & 6.89 & 7.09 & 6.79 \\
\hline A/CNK & 1.12 & 1.15 & 1.04 & 1.23 & 1.15 & 1.05 & 1.02 & 1.19 & 1.05 & 1.16 \\
\hline A/Nk & 1.34 & 1.36 & 1.19 & 1.45 & 1.39 & 1.25 & 1.35 & 1.44 & 1.19 & 1.40 \\
\hline \multicolumn{11}{|c|}{ Trace elements } \\
\hline $\mathbf{N i}$ & i & 2 & 27 & 3 & 2 & $-i$ & 3 & $\overline{1}$ & i & 2 \\
\hline $\mathbf{C u}$ & 7 & 5 & 7 & 10 & 8 & 7 & 6 & 10 & 7 & 9 \\
\hline $\mathbf{Z n}$ & 43 & 43 & 46 & 42 & 55 & 37 & 40 & 39 & 49 & 42 \\
\hline $\mathbf{Z r}$ & 226 & 266 & 289 & 247 & 281 & 255 & 244 & 275 & 252 & 210 \\
\hline $\mathbf{Y}$ & 138 & 165 & 167 & 139 & 163 & 153 & 150 & 161 & 141 & 127 \\
\hline $\mathbf{P b}$ & 114 & 125 & 129 & 116 & 122 & 156 & 122 & 110 & 112 & 111 \\
\hline $\mathbf{G a}$ & 89 & 79 & 88 & 106 & 29 & 94 & 112 & 81 & 106 & 65 \\
\hline $\mathbf{R b}$ & 40 & 30 & 36 & 28 & 36 & 23 & 26 & 29 & 27 & 28 \\
\hline $\mathbf{B a}$ & 31 & 33 & 27 & 23 & 39 & 35 & 36 & 22 & 24 & 39 \\
\hline Sr & 8 & 9 & 10 & 10 & 9 & 9 & 8 & 10 & 9 & 7 \\
\hline Nb & 41 & 49 & 51 & 45 & 50 & 47 & 44 & 49 & 44 & 38 \\
\hline
\end{tabular}

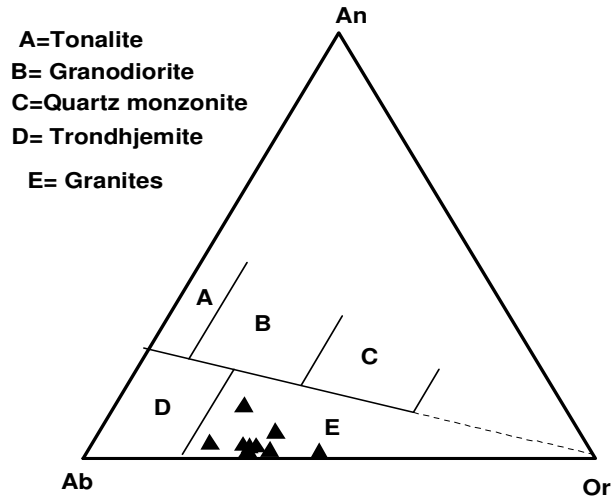

Fig.11: Normative Ab-Or-An ternary diagram (Barker, 1979) muscovite leucogranites covite leucogranite samples lie in granite field.

The A/NK versus A/CNK binary diagram was constructed by Maniar and Piccoli, (1989) to distinguish the different peraluminous, metaluminous and peralkaline magma types. The muscovite leucogranites samples fall in the peraluminous field (Fig.12).

The $\mathrm{K}_{2} \mathrm{O}-\mathrm{SiO}_{2}$ relationship (Le Maitre, 1989 and Rickwood, 1989), (Fig. 13) indicates that the studied muscovite leucogranite samples plot in the calc-alkaline rock series field (medium-K). Sylvester, (1989) used major oxides for discrimination between alkaline, calc-alkaline, and alkaline and highly fractionated calc-alkaline magmas (Fig. 14). The ma- 


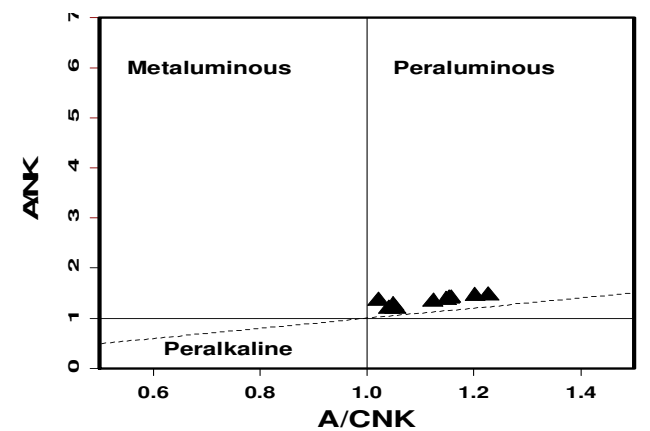

Fig.12: A/NK vs.A/CNK discriminat ion binary diagram (Maniar and Piccoli, 1989), muscovite leucogranites

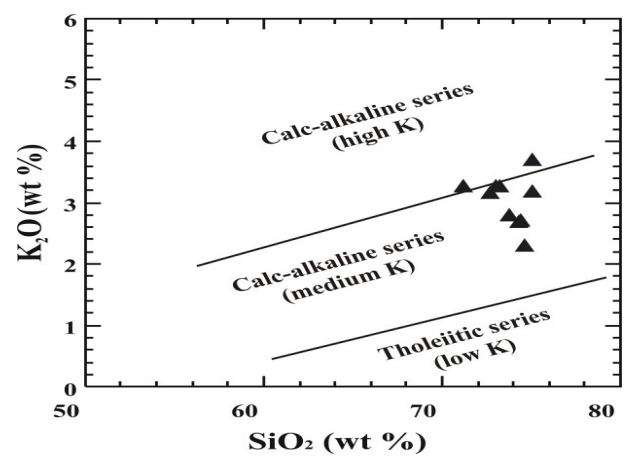

Fig.13: The $\mathrm{K}_{2} \mathrm{O}-\mathrm{SiO}_{2}$ relationship (Le Maitre 1989 and Rickwood, 1989), muscovite leucogranites

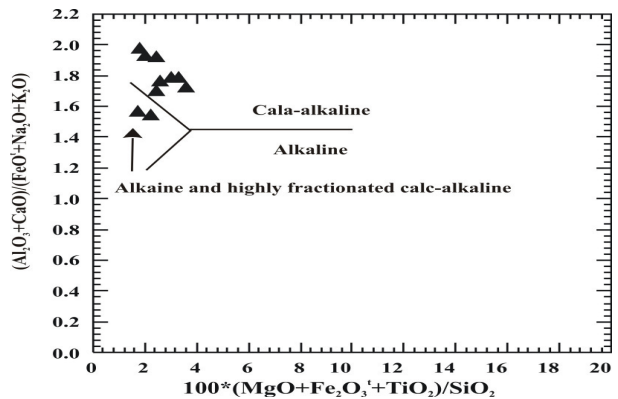

Fig.14: Major oxides discrimination diagram (Sylvester 1989) . muscovite leucogranites jority of studied samples lie in calc- alkaline field except two samples lie in alkaline and highly fractionated calc-alkaline field.

$\mathrm{Na}_{2} \mathrm{O}$ vs. $\mathrm{K}_{2} \mathrm{O}$ binary diagram (Fig. 15) reveals three types of granite in three fields; I-type and S-type after White and Chappell, (1984) and A-type after Liew et al., (1989). Most of the examined samples of muscovite leucogranites plot in the A-type field at the border of the I-type field. Variation diagram of $\mathrm{SiO}_{2}$ versus $\mathrm{Zr}$ (Newberry et al.,1990) show that the most studied muscovite leucogranite samples lie in A-type granite (Fig. 16).

The tectonic setting of the studied muscovite leucogranites are elucidated using the

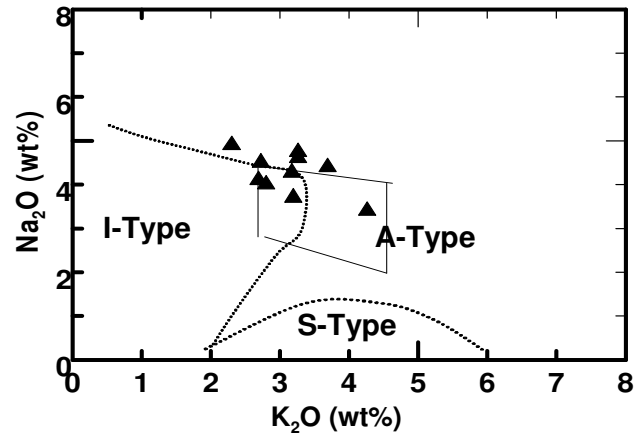

Fig. 15: $\mathrm{Na}_{2} \mathrm{O}$ vs. $\mathrm{K}_{2} \mathrm{O}$ binary diagram (White and Chappell, 1984), modified by Liew et. al., 1989), muscovite leucogranites

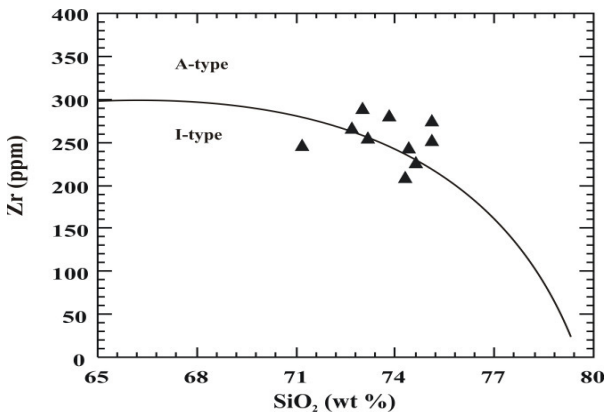

Fig. 16: $\mathrm{SiO}_{2}$ vs. $\mathrm{Zr}$ variation diagram (Newberry et al.1990), muscovite leucogranites. 
$\mathrm{Nb}$ against $\mathrm{Y}$ discrimination diagram (Fig.17) was used by Pearce et al. (1984) to distinguished four tectonic fields of granite; Within plate granite (WPG), Syn-collision granite (Syn-COLG), Volcanic arc granite (VAG) and Oceanic ridge granite (ORG). The muscovite leucogranites belong to within plate tectonic setting field.

$\mathrm{Rb}$ and $\mathrm{Sr}$ are distributed in the granitoids rocks based on the abundance of K-feldspar (for $\mathrm{Rb}$ ) and Ca-plagioclase (for $\mathrm{Sr}$ ). Both $\mathrm{K}$-feldspars and Ca-plagioclase are directly related to crustal fractionation and hence to its thickening where the thickness of crust increases with the increase $\mathrm{Rb}$ and $\mathrm{Sr}$ contents. $\mathrm{Rb}$ against $\mathrm{Sr}$ binary diagram, which established by Condie (1973) is used to determine the crustal thickness during the intrusion of any magmatic rocks. Based on this diagram, the muscovite leucogranites are intruded in a continental crust with thickness average about $<20 \mathrm{~km}$. (Fig.18).

The $\mathrm{Ba} / \mathrm{Rb}$ ratio decreases with magmatic differentiation due to crystallization of feldspars. $\mathrm{Ba} / \mathrm{Rb}$ ratio for granites suggested by Mason, (1966) is 4.1. The Ba-Rb variation diagram (Fig.19) shows that the muscovite leucogranite samples lie between 4.4 to $4.4 \times 10^{-1}$. This ratio equal the average crustal value, indicating the addition of crustal magma in the formation of muscovite leu-

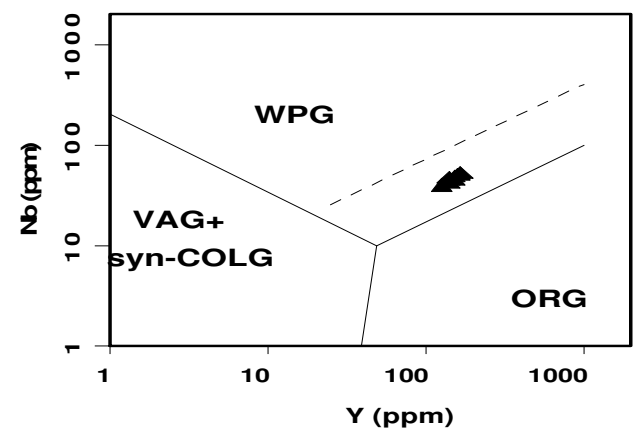

Fig. 17: Nb vs. Y tectonic discrimination diagram (Pearce et al., 1984), muscovite leucogranites.

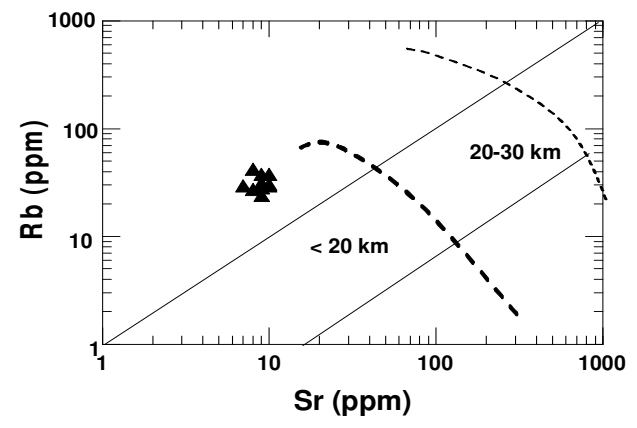

Fig. 18 : Rb vs. Sr binary diagram (Condie, 1973), muscovite leucogranites.

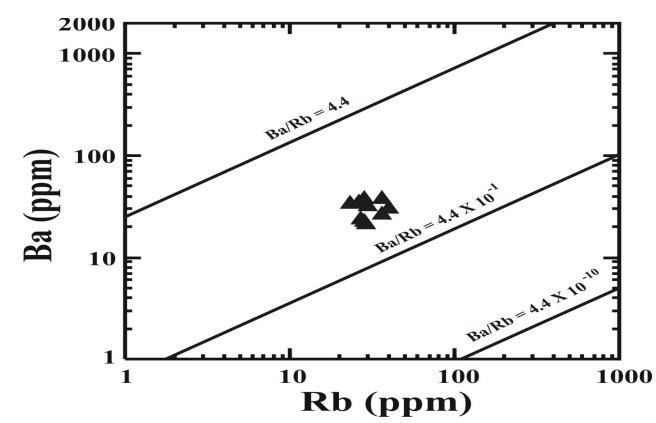

Fig. 19 : Ba vs. Rb binary diagram (Mason 1966) for the muscovite leucogranite

cogranites.

Spider diagram of normalized element data of muscovite leucogranites relative to chondrite by Thompson, (1982) is given in (Fig. 20). It can be observed that the muscovite leucogranites pattern have enrichment of $\mathrm{Rb}, \mathrm{Nb}, \mathrm{Pb} \mathrm{Y}, \mathrm{Ba}$, and $\mathrm{Zr}$, which is a characteristic of dominated crustal materials in the parent magma (Pearce et al.,1984). It also shows depletion of $\mathrm{Cu}, \mathrm{Zn}$, and $\mathrm{Ni}$.

\section{MINERALOGY OF MUSCOVITE LEUCOGRANITES}

Three samples (10 kg. For each samples) were crushed and the size fraction of 0.063 $0.5 \mathrm{~mm}$ was used. This size fraction was sub- 


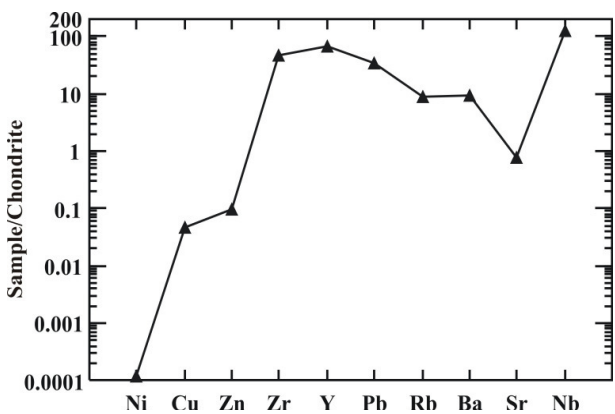

Fig. 20: Spiderdiagram of normalized elements data of muscovite leucogranites. Normalized values refer to chondrite of Thompson, 1982.

jected to systematic mineral separation techniques using heavy liquids (Bromoform, 2.8 sp.gr.), magnetic fractionation using (Frantz Isodynamic Magnetic Separator) and microscopically handpicking mineral grains. Mineral identifications were carried out by Environmental Scanning Electron Microscope (ESEM) techniques. The obtained minerals include:

\section{Uranophane $\left(\mathrm{CaO} .2 \mathrm{UO}_{3} .2 \mathrm{SiO}_{2} .6 \mathrm{H}_{2} \mathrm{O}\right)$}

The uranophane grains under the microscope are present as massive radiated. The crystals exhibit poorly developed faces and do not afford good morphological measurements. The grains are very soft with canary to pale yellow colors (Fig21 \&22).

\section{Thorite $\left(\mathrm{ThSiO}_{4}\right)$}

In the investigated area, thorite occurs as short prismatic crystals exhibiting deep brownish color (Figs. 23\&24). Because thorite is highly radioactive it is usually metamict and contains REEs in few percent with Ce, uranium and yttrium.

\section{Zircon $\left(\mathrm{ZrSiO}_{4}\right)$}

Most of zircon is represented by prismatic grains with bipyramidal or broken crystals with subrounded edges. The grains are colourless to honey in colors (Figs.25 \&26). Metamictization in minerals is generally considered to

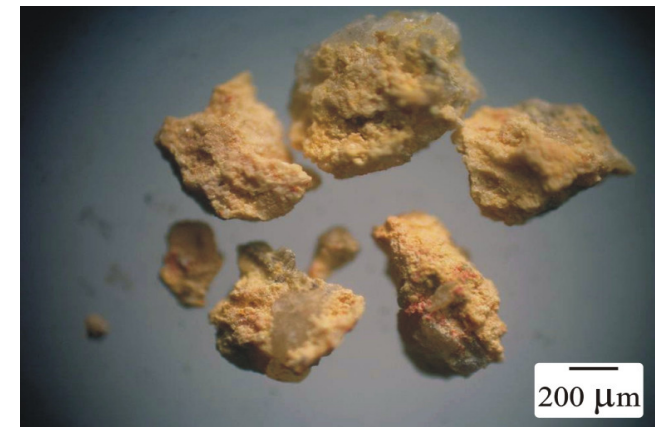

Fig. 21 : Canary to pale yellow uranophane, muscovite leucogranites, Wadi Abu Rusheid area

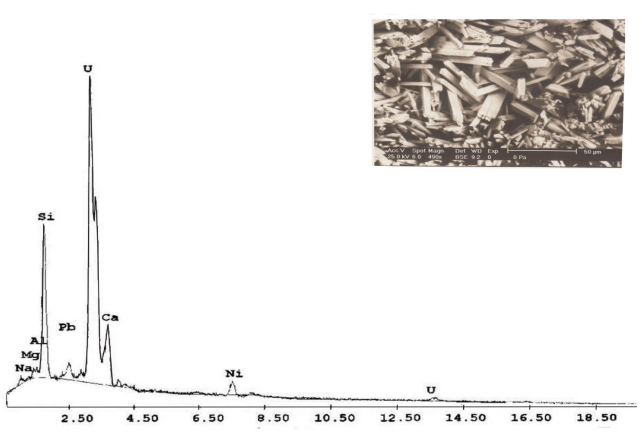

Fig. 22: ESEM photomicrograph of uranophane, muscovite leucogranites

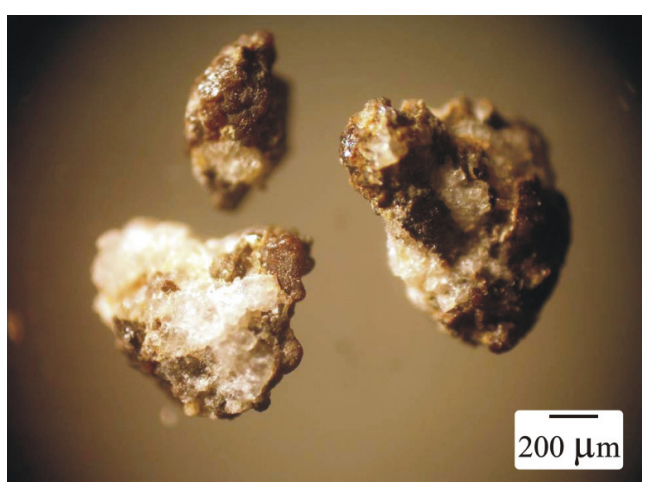

Fig. 23: Deep brown thorite. muscovite leucogranites, Wadi Abu Rusheid area. 


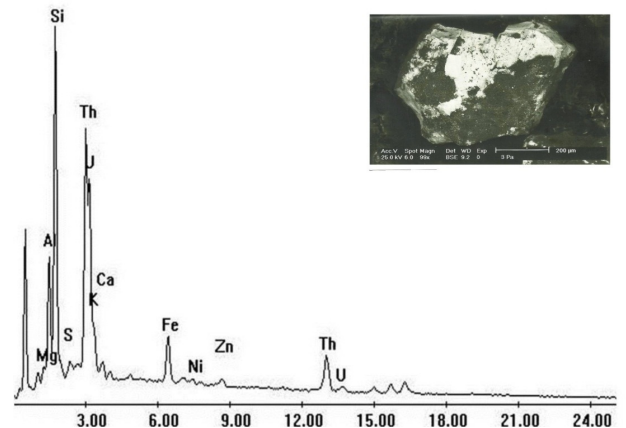

Fig. 24 : ESEM photomicrograph of thorite, muscovite leucogranites,

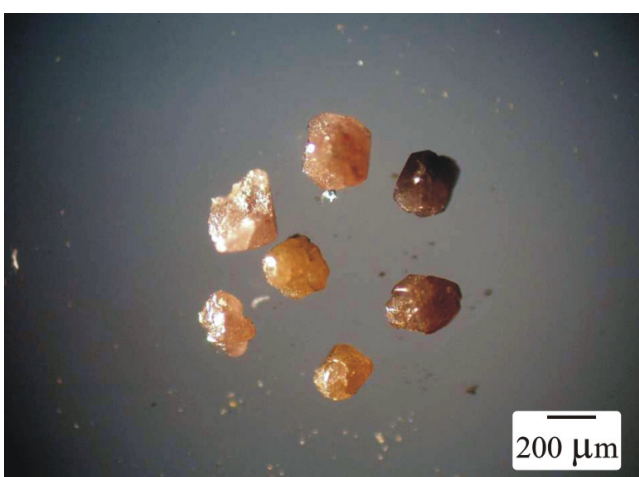

Fig. 25: Photomicrograph showing colorless to honey zircon.

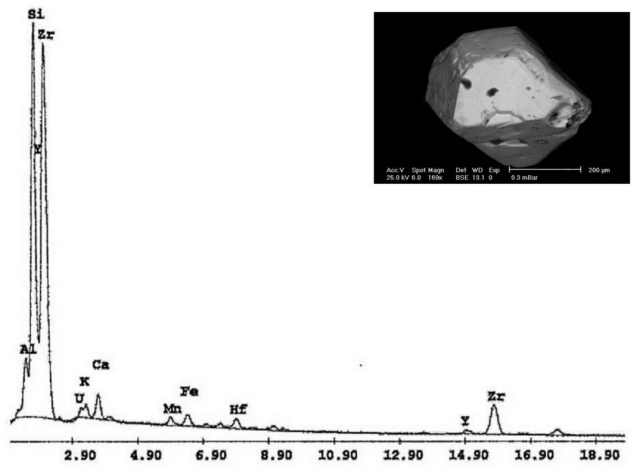

Fig. 26; ESEM photomicrograph of zircon, from muscovite leucogranites, Wadi Abu Rusheid area. be the effect of radiation damage produced by radioactive decay of thorium and uranium, (Mitchell,1973). The crystal habit of zircon in the investigated rocks of study area is short prismatic crystals.

The cataclastic rocks had been studied by many workers (Ibrahim, et al.,2004; Rashed, 2005 and Darwish, 2014) and characterized by containing poly-mineralizations. Comparison between mineralizations in study muscovite leucogranites and cataclastic rocks are listed in Table (2):

\section{SPECTROMETRIC PROSPECTING}

The instrument used in the ground $\gamma$-ray spectrometric survey measurements is RS230. Ground $\gamma$-ray spectrometric survey can detect dose rate (D.R.) in unit (nanosieverts per hour (nSv h-1)), potassium (K\%), equivalent uranium content (eU ppm), and equivalent thorium content (eTh ppm). Uranium mobilization $(\mathrm{eUm})$ in the studied rock types can be calculated as follows: the uranium mobilization is calculated difference between the measured $\mathrm{eU}$ and the expected original uranium, which is calculated by dividing the measured eTh by the average eTh/eU ratio in the crustal acidic rocks (original uranium $=$ eTh / 3.5 according to Clark et al., 1966) to give the leaching values of uranium $(\mathrm{eUm}=$ $\mathrm{eU}-\mathrm{eTh} / 3.5$ ). Positive values indicate ura-

Table 2 : Comparison between mineralizations in muscovite leucogranites and cataclastic rocks.

\begin{tabular}{lrr}
\hline & Muscovite leucogranites & Cataclastic rocks \\
\hline Uranium minerals & Uranophane & $\begin{array}{r}\text { Uranophane, casolite } \\
\text { and autonite }\end{array}$ \\
Thorium minerals & Thorite & $\begin{array}{r}\text { Thorite and } \\
\text { uranothorite }\end{array}$ \\
Associated minerals & zircon & $\begin{array}{r}\text { Zircon, xenotime } \\
\text { and cassiterite }\end{array}$ \\
$\begin{array}{l}\text { Niobium- Tantalite } \\
\text { minerals }\end{array}$ & $\ldots$ & Columbite \\
Sulphide minerals & $\ldots---{ }^{---}$ & $\begin{array}{r}\text { Pyrite, chalcopyrite, } \\
\text { galena and covellite }\end{array}$ \\
\hline
\end{tabular}


nium addition by mobilization, whereas negative values indicated migration of uranium by leaching. D.R., K\%, eU, eTh, and other variants of cataclastic rock and muscovite leucogranit are illustrated in Table (3).

Normally, Th is three times as abundant as $\mathrm{U}$ in natural rocks (Rogers and Adams, 1969). When this ratio is disturbed, it illustrates a depletion or enrichment of uranium. $\mathrm{U}$ and $\mathrm{Th}$ contents of granitic rocks generally increase during differentiation although in some cases they decrease (Ragland et al.,1967). Th/U ratio can either increase or decrease as it is controlled by the redox conditions, volatile contents, or alteration by endogens or supergene solutions (Falkum and Rose-Hansen, 1978). Relation between uranium and thorium is helpful to test if there is enrichment or depletion of uranium and/or thorium.

In the cataclastic rocks the eU contents range from $20-110 \mathrm{ppm}$ with average about $60 \mathrm{ppm}$. The eTh contents range between 55 $418 \mathrm{ppm}$ with average about $150 \mathrm{ppm}$. The $\mathrm{eU} / \mathrm{eTh}$ ratio ranges between $0.2-1$ with average about 0.45 , more than the magmatic eU/ eTh ratio ( 0.33 ), indicating the enrichment of uranium in the cataclastic rocks. The uranium mobilization $\{\mathrm{eUm}=(\mathrm{eU}-\mathrm{eTh} / 3.5)\}$ of cataclastic rocks ranges from -20 to 40 with an average about 16. These positive value of eUm indicating also the migration of uranium into the cataclastic rocks (Table 3 ).

In muscovite leucogranites, the eU contents range from $12-250 \mathrm{ppm}$ with average about $80 \mathrm{ppm}$. The eTh contents range be- tween 60-1146 ppm with average about 380 ppm. The eU/eTh ratio ranges between 0.15 -0.29 with average about 0.21 less the magmatic eU/eTh ratio $(0.33)$, indicating that migration out of uranium from the muscovite leucogranites. The uranium mobilization \{ $\mathrm{eUm}=(\mathrm{eU}-\mathrm{eTh} / 3.5)\}$ of muscovite leucogranite range from 0 to -84 with an average about -28 . These negative values of eUm indicating the migration out of uranium from the muscovite leucogranites (Table 3 ).

The average eU content in both cataclastic rocks and muscovite leucogranite are more than twice their Clark value (4 ppm). This indicates that these rocks are uraniferous rocks.

The variation diagrams of the cataclastic rocks, (Figs.27-29) showing there are weakly positive relation between eU vs .eTh. This relation indicating, post-magmatic redistribution of uranium, leading to the enrichment of

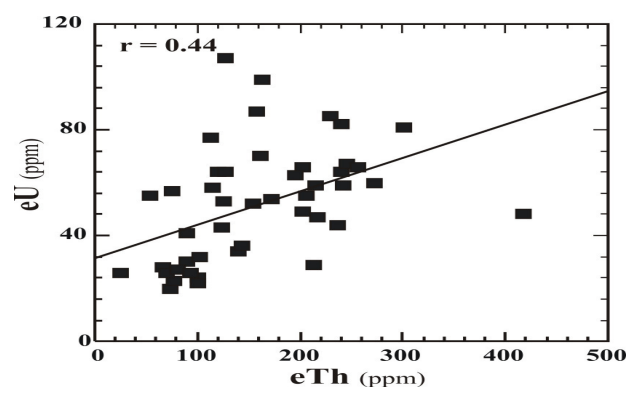

Fig. 27 :Binary variation diagram between eU vs. eTh, ctaclastic rocks.

Table (3); The range and average of D. R., K\%, eU, eTh and eU/eTh of muscovite leucogranites and cataclastic rocks

\begin{tabular}{lrrrrrr}
\hline Rock types & D.R. $(\mathbf{n S v}$ h-1) & K\% & eU ppm & eTh ppm & eU/eTh & UUm \\
\hline $\begin{array}{l}\text { Muscovite } \\
\text { leucogranites }\end{array}$ & $320-5000$ & $1.7-3.7$ & $12-250$ & $60-1146$ & $0.15-0.29$ & $0-(-84)$ \\
$\begin{array}{l}\text { Average } \\
\text { Cataclastic }\end{array}$ & 950 & 2.2 & 80 & 380 & 0.21 & -28 \\
$\begin{array}{l}\text { rocks } \\
\text { Average }\end{array}$ & $360-1400$ & $3.1-7$ & $20-110$ & $55-418$ & $0.2-1$ & $(-20)-(40)$ \\
& 830 & 4.5 & 60 & 150 & 0.45 & 16 \\
\hline
\end{tabular}


A. RASHED

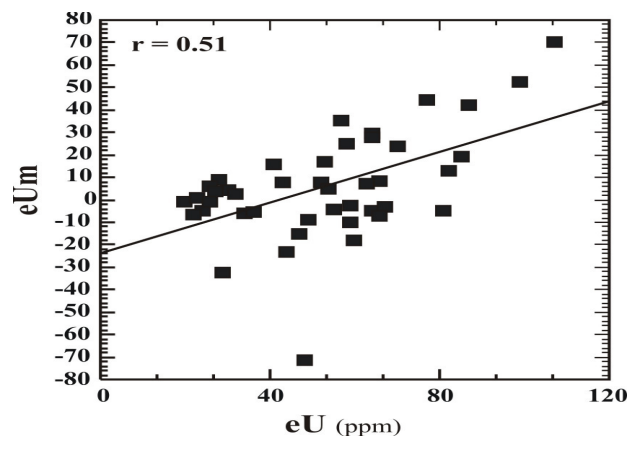

Fig. 28:Binary variation diagram between eU vs. eUm, cataclastic rocks

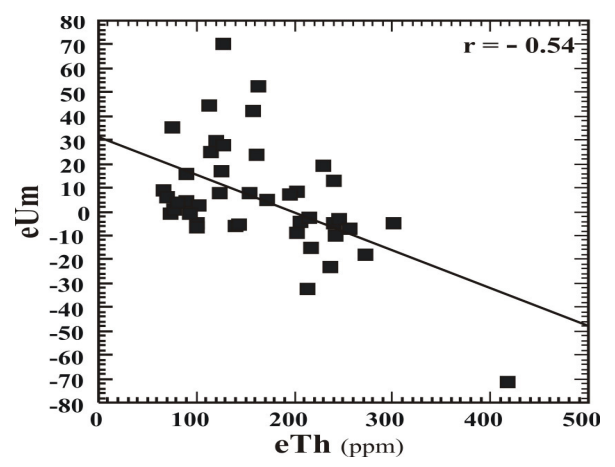

Fig. 29:Binary variation diagram between eUm vs. eTh, cataclastic rocks

uranium. The relations between eUm vs. eU in one hand and eTh in the other hand show positive relation with eU and negative relation with eTh. These relations also indicating the enrichment of uranium later by post-magmatic processes.

The variation diagrams of the studied muscovite leucogranites (Figs. 30-32) show that, there is a very strong positive relation between eU vs eTh, indicating magmatic origin. The relation between eUm vs. eU and eTh showing strong negative relations. These negative relations reflect the migration out and losing some of original uranium from the muscovite leucogranites.

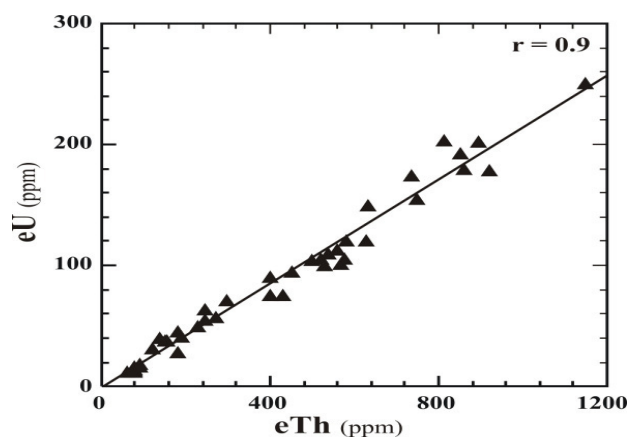

Fig. 30 :Binary variation diagram between eU vs. eTh, muscovite leucogranites.

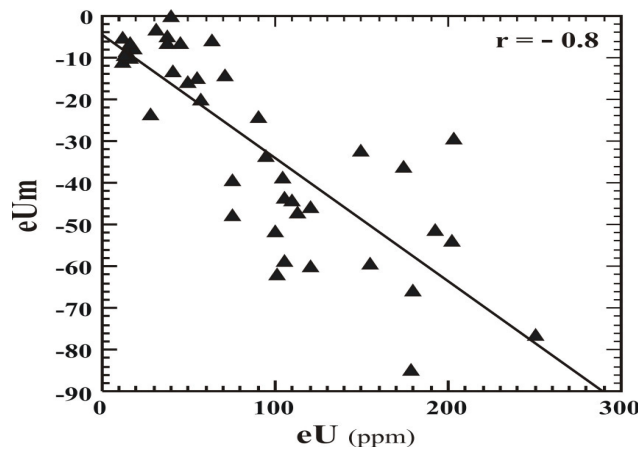

Fig. 31:Binary variation diagram between eU vs. eUm muscovite leucogranites

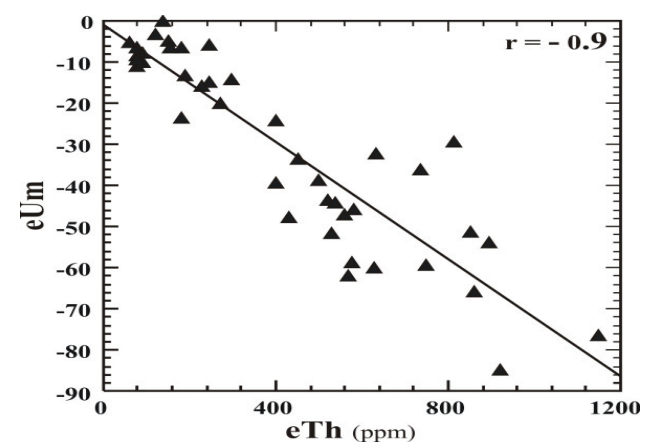

Fig. 32 :Binary variation diagram between eUm vs. eTh, muscovite leucogranites 
From above variation diagrams in all cataclastic rocks and muscovite leucogranites, it is clear that the muscovite leucogranites lose some of their uranium contents. This losing part of uranium contents from muscovite leucogranites is migrated out and re-deposited in the cataclastic rocks. So that, the muscovite leucogranites play a role in the occurrences of uranium mineralizations in the cataclastic rocks in Abu Rusheid area.

From above studies, we can concluded that, the origin of the high radioactivity of muscovite leucogranites is related magmatic in origin, for these reasons:

1- High contents of uranium (from 12 to $250 \mathrm{ppm}$ ) and thorium ( from 60 to $1146 \mathrm{ppm}$ ) in muscovite leucogranies with very strong positive relation between them. It known that the thorium not mobilized and stay in the hosted rocks.

2-The muscovite leucogranites are fresh with absence of any alteration processes (absence of hydrothermal solutions).

3 . The muscovite leucogranites are poorly in accessory minerals.

4. The absence of post-magmatic activities (dykes or veins).

\section{CONCLUSIONS}

1-The study area at north Wadi Abu Rusheid consists mainly of ophiolitic mélange cataclastic rocks, biotite granites and muscovite leucogranites.

2-The muscovite leucogranites were intruded through the contact between the ophiolitic mélange and the cataclastic rocks paralling to the foliations of metasediments of ophiolitic mélange along the thurst fault. This emplacement leading to the muscovite leucogranites suffered degree of deformation and cataclasis. Petrographically, these rocks are composed mainly of quartz, plagioclase of albitic composition, potash feldspare and muscovite. Thorite, zircon, uranophane and opaques are accessory minerals.

3-Th presence of bent, kinked and gliding of plagioclase lamellae as well as high cracking and strongly undulatory quartz, all these features point to subsolidus deformation (Paterson et al., 1989). Such deformation should be the result of extensive regional thrusting (Greiling et al.,1987) to which the area had been subjected.

4-The studied muscovite leucogranites have high $\mathrm{SiO}_{2}, \mathrm{Al}_{2} \mathrm{O}_{3}$ alkali contents, $\mathrm{Zr}, \mathrm{Y}$, $\mathrm{Pb}, \mathrm{Ga}$ and $\mathrm{Nb}$ and posses low $\mathrm{TiO}_{2}, \mathrm{MgO}$, $\mathrm{CaO}, \mathrm{FeO}$ and $\mathrm{P}_{2} \mathrm{O}_{5}$ contents. The muscovite leucogranites are originated from magma characterized by peraluminous in nature, sodic rich magma, calc-alkaline and belong to A-type field. The muscovite leucogranites belong to within plate tectonic setting and intruded in a continental crust with thickness average $<20 \mathrm{~km}$.

5- The muscovite leucogranites have high contents of radioactivity in the studied area ( eU up to $250 \mathrm{ppm}$ and eTh up to 1146 ppm) due to the presence of uranophane and thorite. The average eU/eTh ratios in muscovite leucogranites equal to 0.21 , while in cataclastic rock equal to 0.45 . This indicates that the muscovite leucogranites suffered migration out of uranium towards the cataclastic rock.

\section{REFERENCES}

Abdel- Rahman, A.M.., and Martin, R.F., 1987. Late Pan- African magmatism and crustal development in northeastern Egypt. Geol. J. 22, 281-301.

Abdel- Rahman, A.M., and Martin, R.F., 1990. The mount Gharib A-type granite, Nubian Shield: petrogenesis and role of metasomatism at the source. Contri. Mineral. Petrol., 104, 173-183.

Abu El Atta, S.A.,; Khaleal, F.A., and Rashed, M. A., 2013. Characteristic of Madinat Nugrus peraluminous leucogranite carrier of radioactive minerals, south Eastern Desert, Egypt. Research Open J. Mineral and Mining Engineer- 
ing, 1 , No. 7, 15-34.

Bailey, D.K., and MacDonald, R.., 1969. Alkalifeldspar fractionation trends and the derivation of Peralkaline liquids. Am. J. Sci., 267, 242248.

Barker, F., 1979.Trondhjemites definition, environment and hypotheses of origin. In: trondhjemites, dacites and related rocks (Barker, Ed.). Developments in petrology. El Sevier Publish. Co., Amsterdam, 6, 1-12.

Batchelor, R.A., and Bowden, P., 1985. Petrogenetic interpretation of granitoid rock series using multicationic parameters. Chem. Geol., 48, $43-55$.

Clarke, S.P.; Peterman, Z.E., and Heier, K.S., 1966. Abundance of uranium, thorium and potassium, In: Handbook of physical contacts(Clarke, S.P. , Ed.). Geol. Soc. Am. Mem. 97 sections , 24, 521-541.

Condie, K.C., 1973. Archean magmatism and crustal thickening. Geol. Soc. Amer. Bull., 84, 2981-2992.

Couyat, J., 1911. Quelques mineraux d'Egypt et du Sinai. Bull. Soc. Franc. Mineral., 35, 560-565.

Darwish, M.E., 2014. Mineralogical investigations and physical upgrading of Abu Rusheid cataclastic rocks, South Eastern Desert, Egypt. Nuclear Sciences Scientific Journal, 3, 1-13.

Deer, W.A.; Howie, R.A., and Zussman, J., 1992. An introduction to the rock forming minerals. Longman group limited, London, England. $2^{\text {nd }}$ Edition.

El Gaby, S., and Habib, M.S., 1982. Geology of the area south west of Port Safaga with special emphasis on the granitic rocks. Eastern Desert, Egypt. Ann. Geol. Surv. Egypt, 12, 47-71.

El-Maghraby, A.M.O., 1994. Geology, petrology and geochemistry of the Precambrian rocks between Wadi Ghadir and Wadi El-Gemal, Eastern Desert, Egypt. Ph. D. Thesis, Cairo Univ. Egypt. 226p.

El Sayed, M.M., 1998. Tectonic setting and petro- genesis of the Kadabora pluton: a late Proterozoic anorogenic A-type younger granitoid in the Egyptian shield. Chemie erde , 58, 38-63.

Emmons, R.S., 1953. Selected petrographic relationship of plagioclase. Geol. Soc. Am., $52,41 \mathrm{p}$.

Falkum, T., and Rose-Hansen, J., 1978. The application of the radioelement studies in solving petrological problems of the Precambrian intrusive Homme granite in the Flekkefjord area, South Norway. Geol., 239, 73-86.

Goldschimdt, V.M., 1954. Geochemistry, Oxford Univ. Press, Oxford, England.

Greenberg, J.K., 1981. Characteristics and origin of Egyptian younger granites. Geol. Soc. America Bull., part I, 92, 224-256.

Greiling, R.O.; Kroner, A.; El Ramly, M.F., and Rashwan, A,A., 1987. Structural relationships between the southern and central parts of the Eastern Desert of Egypt; Details of a fold and thrust belt. In: The Pan-African belt of NE Africa and adjacent areas-tectonic evolution and economic aspects of a late Proterozoic orogen (El Gaby, S., Greiling, R. , Eds.). Vieweg. Wiesbaden., 121-145.

Hassan, M.A., 1973. Geology and geochemistry of radioactive columbite- bearing psammitic gneiss of Wadi Abu Rusheid. South Eastern Desert, Egypte. Ann. Geol. Surv. Egypt., III, 207-225.

Hassan, M.; El-Bakry , H.; Al-Amin, E. , and Al Bassiony, Q., 1984. Geochemical orientation survey of tungsten mineralization in arid conditions, Eastern Desert, Egypt. Bull. Fac Sci. Zagazig Univ., 6, 38-54.

Hassanen, M.A.; Saad, N.A., and Khalefa, O. M., 1995. Geo-chemical aspects and origin of Tibearing granites in Egypt. Acta MineralogiePetrographie Szeged, 36, 55-72.

Hassanen, M.A., and Harraz, H.Z., 1996. Geochemistry, Sr- and Nd isotopic study on the rare-metals bearing granitic rocks, Central Eastern Desert. Egypt. Precambrian Research, 80, 1-22. 
Hassanen, M.A., 1997. Post-collision, A-type granites of Homrit Waggat complex, Egypt: petrological and geochemical constraints on its origin. Precambrian Research, 82, 211-238.

Hussein, A.A.; Ali, M.M., and El Ramly, M.F., 1982. A proposed new classification of the granites of Egypt. J. Volcanology Geothermal Research, 14, 187-198.

Ibrahim, M.E.; Saleh, G.M.; Amer, T.; Mahmoud, F.O.; Abu El Hassan, A.A.; Ibrahim, I.H.; Aly, M.A.; Azab, M.S.; Rashed, M.A.; Khaleal, F. M., and Mahmoud, M.A., 2004. Uranium and associated rare metals potentialities of $\mathrm{Abu}$ Rusheid brecciated shear zone II, south Eastern Desert, Egypt. (Internal report), 157p.

Le Maitre, R.W., 1989. A classification of igneous rocks of terms., Blackwell Sci. Bull. Oxford, London, $171 \mathrm{p}$.

Liew, T.; Finger, F., and Hock, V., 1989. The molybdanubian granitiod plutonic of Austria, chemical isotopic studies bearing their environmental setting. Chem. Geol., 76, 41-55.

Mahmoud, M.A., 2009. Highlight on the geology, geochemistry and spectrometry of the muscovite granites at Wadi El Gemal area, South Eastern Desert, Egypt. Ph.D. Fac. Sci., Suez Canal Univ., 217p.

Maniar, P.D., and Piccoli, P.M., 1989. Tectonic discrimination of granitiods. Geol. Soc. Am. Bull., 101, 635-643.

Mason, D., 1966. Principals of geochemistry. $3^{\text {rd }}$ Edition, Jhon Wiley and Sons, New York, 310 p.

Mitchell, R.S., 1973. Metamict minerals: A review. Pt. I, Chemical and physical characteristics, occurrence. Pt. II, Origin of metamictization, methods of analysis, miscellaneous topics. Mineral. Rec., 4, 177-182, 214-223.

Nabelek, P.I., and Mian, L., 2004. Petrologic and thermal constraints on the origin of leucogranites in collisional orogens. Transactions of the Royal Society of Edinburgh. Earth Sciences, 95, 73-85.
Newberry R.J.; Burns, L.E.; Swanson, S.E., and Smith, T.E., 1990 . Comparative petrologic evolution of the Sn and W granites of the Fairbanks- Circle area, interior Alaska. In: Orebearing granite systems; petrogenesis and mineralizing processes (Stein,HJ. and Hannah, JL. , Eds.). Geolo. Soc. Amer. Special Paper, 121-142.

Paterson, S.R..; Vernon, R.H., and Tobisch, O.H., 1989. Preview of criteria for the identification of magmatic and tectonic foliations in granitiods. J. structrual Geol., 11, 340-363.

Pearce, J.A.; Harris, N.B.W. and Tindle, A.G., 1984. Trace element discrimination diagrams for the tectonic interpretation of granitic rocks. J. Petro., 25, 958-983.

Ragab, A.I.; Menesy, M.Y., and Diab, M.M., 1989. Petrology and petregenesis of the Older and Younger Granitoids of Wadi Beizah area, Central Eastern Desert, Egypt. J. Afri. Earth Sci., 9, 303-315.

Ragland, P.C.; Billing G.K., and Adams, J.A.S., 1967. Chemical fractionation and its relationship to the distribution of thorium and uranium in zoned granite batholiths. Geochem. Cosmochem. Acta, 31, 17-33.

Rashed, M.A., 2005. Geologic studies on a new occurrence of nuclear materials in abu rusheid area, south eastern desert, Egypt. Ph. D. Thesis, Fac. Sci. ( Damietta ), Mansoura Univ., 144 p.

Rickwood, P.C., 1989. Boundary lines within petrologic diagrams which use oxides of major and minor elements. Lithos, 22, 247-263.

Rogers, J.J.W., and Adams, J.A.S., 1969a. Uranium and thorium, In: Handbook of Geochemistry (Wedepohl, K.H., Ed.) , 11-3, 92-B-1 to 92-05 , Springer Verlag. Berlin.

Royden, L.H., 1993. The steady-state thermal structure of eroding orogenic belts and accretionary prisms; J. Geophys. Res., 98, 4, 487-4, 507p.

Sabet, A.H.; Tsogoev, V.B.; Bordonosov, V.P.; Shoblovsky, R.G., and Kossa, M. 1976. On the geologic structures, laws of localization and 
prospects of Abu Rushied rare metals deposit Annals. Geol. Surv. Egypt., VI., 181-197.

Saleh, G.M., 1997. The potentiality of uranium occurrences in Wadi Nugrus area, south Eastern Desert, Egypt. Ph. D. Thesis, Mans. Univ., 171 p.

Shelley, D., 1993. Igneous and metamorphic rocks under the microscope. Chapman and Hall, London.

Stern, R.J., 1985. The Najed fault system, Saudi Arabia and Egypt: A late Precambrian reft-related transform system. Tectonics, 4, 497-511.

Sylvester, P., 1989. Post collision alkaline granites. J. Geol., 97, $261-280$.
Takla, M.A., and Nowier, A,M., 1980. Mineralogy and mineral chemistry of the ultramafic mass of El- Rubshi, E. D., Egypt. Neves Jahrb. Min. Abh., 140/1, 17-28.

Thompson, A.B.,1982. British Tertiary volcanic province. Scott. J. Geol., 18, 49-107.

Thompson, A.B., and Connolly, J.A.D., 1995. Melting of the continental crust: Some thermal and geological constraints on anatexis in contienental collision zones and other tectonic settings. J. Geophy. Research 100, 15, 565-79.

White, A.J.R., and Chappell, B.W., 1984. Granitoids types and their distribution in the Lachlan Fold Belt. South Eastern Australia, Geol. Soc. Men., 159, p.21-34.

\footnotetext{
جيولوجية واشعاعية ا لليكوجرانيت المسكوفيتى فى شمال وادى ابو رشيا, جنوب الصحراء الشرقية, مصر في فمر

محمد عبد الله راثن

منطقة الدراسة تقع عند شماال و ادى ابو رشيد و تتكون جيولوجيا من (الاقدم )صخور الميلانج

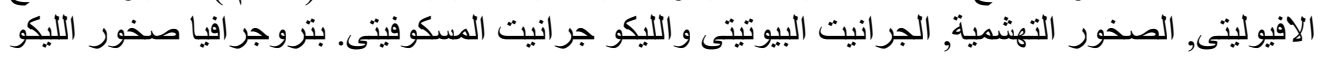

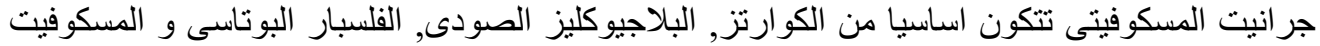
بينما الزركون و المعادن المعتمة و الثوريت موجودة الثنات بنسبة شحيحة.

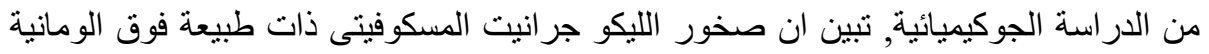

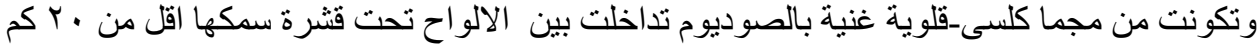

من الدراسة المعدنية,تبين ان صخور الليكو جر انيت المسكوفيتى يحتوى على معادن اليور انوفين,

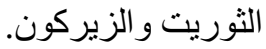

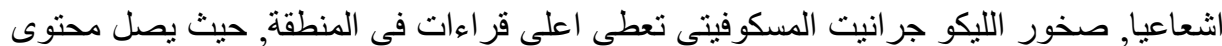

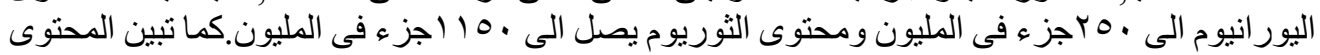

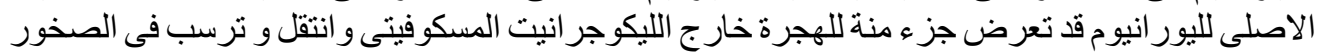

